\title{
STUDY OF ACUTE AND SUB-ACUTE TOXICITY OF Boehmeria virgata (FORST) GUILL LEAF EXTRACT IN WISTAR RATS
}

\author{
Marianti Manggau ${ }^{1}$, Endang Kusuma $\operatorname{Intan}^{1}$, Maghfirah $^{1}$, Wira Bahari Nurdin ${ }^{2 *}$, \\ Husni Cangara ${ }^{3}$, Kim Dong-Seok ${ }^{4}$
}

${ }^{1}$ Faculty of Pharmacy, Hasanuddin University, Indonesia

${ }^{2}$ Faculty of Mathematics and Natural Sciences, Hasanuddin University, Indonesia

${ }^{3}$ Faculty of Medicine, Hasanuddin University, Indonesia

${ }^{4}$ Medicine College, Chung-Ang University, South Korea

Received - December 26, 2020; Revision - March 27, 2021; Accepted - May 08, 2021

Available Online - September 08, 2021

DOI: http://dx.doi.org/10.18006/2021.9(Spl-2-ICOPMES_2020).S248.S258

\section{KEYWORDS \\ Boehmeria virgate \\ Leaf extract \\ Acute toxicity \\ Sub-acute toxicity \\ Hematology parameters \\ Biochemical parameters \\ Histopathological parameters}

\begin{abstract}
This study was carried out to evaluate the acute and sub-acute toxicity of the standardized Boehmeria virgata leaf extract (BLVE) in Wistar rats. B. virgata is a traditional herb utilized by the people of Makassar, Indonesia to cure inflammation and cancer. In the current study, thirty (30) Wistar rats were divided into 6 groups ( 3 groups of males and 3 groups of females) for acute treatments. Similarly, for investigating sub-acute treatment forty (40) Wistar rats were split into 8 groups (4 groups of males and 4 groups of females). For acute toxicity treatment, selected rats received $2000 \mathrm{mg}$ and $5000 \mathrm{mg} / \mathrm{kg}$ of BVLE by oral administration for 14 days while for the estimation of sub-acute toxicity, experimental rats were treated with 250,500, and $1000 \mathrm{mg} / \mathrm{kg}$ BVLE for 28 days. After 14 days of treatment, the rats were monitored for any form of changes in behavior, weight, food, water intake, and histopathology. The treated animals underwent hematological, biochemical, histopathological, and organ weight analysis after 28 days. Results of the study revealed no significant differences in body and organ weight, intake of food, and water after acute BVLE treatment in rats compared with those in the control group. The histopathological study suggested a general hydropic degeneration of the liver after acute treatment with $5000 \mathrm{mg} / \mathrm{kg}$; such degeneration did not occur in the kidneys and kidney glomerulus of BVLE
\end{abstract}

* Corresponding author

E-mail:wbnurdin@gmail.com (Wira Bahari Nurdin)

Peer review under responsibility of Journal of Experimental Biology and Agricultural Sciences.

Production and Hosting by Horizon Publisher India [HPI] (http://www.horizonpublisherindia.in/).

All rights reserved.
All the articles published by Journal of Experimental Biology and Agricultural Sciences are licensed under a Creative Commons Attribution-NonCommercial 4.0 International License Based on a work at www.jebas.org.

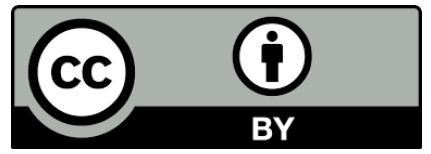


treated rats. Further, no significant toxicity was shown in hematological, biochemical, organ weight, and histopathological data in the sub-acute BVLE group after comparing treated rats with the control group. Results of the study can be concluded that BVLE is not toxic at doses of up to $1000 \mathrm{mg} / \mathrm{kg}$. Therefore $B$. virgate fulfilled a preclinical criterion that is necessary for its further establishment as a clinically useful extract.

\section{Introduction}

Boehmeria virgata (Forst) Guill belongs to the family Urticaceae and has been utilized by the people of Makassar, Indonesia as a traditional medicine to cure inflammation and cancer (Manggau et al., 2011). Ethanolic extract of B. virgata along with Eupatorium odoratum, Acalypha indica, and Acanthus ilicifolius are traditionally used by the Makassar ethnic group as anticancer and antiinflammation agents and have been well-studied for their activity against HeLa cervical cancer cells (Manggau et al., 2013). In addition, Manggau et al. (2018) reported the anti-proliferative activity of BV103 compound on HeLa cell lines and suggested that this might be due to the inhibition of p53 and Caspase-3. Similarly, Wardihan et al. (2013) also suggested the selective cytotoxicity of BVLE on some cancer cell lines, namely HeLa, T47D, WiDr, Vero cells with $\mathrm{IC}_{50}$ of $8.991 \pm 0.234,12.732 \pm 0.945,18.925 \pm 1.277$, and $16.022 \pm 0.663 \mu \mathrm{g} / \mathrm{ml}$ respectively. Moreover, the selectivity index of the extract against HeLa, T47D, WiDr, Vero cells were reported $0.844,1.258,0.847$, and 1.000 respectively. The BVI03 compound (10-6,6-dihydroxy-hexyl-2,3,6-trimethoxy-phenanthrene-9-

carboxylic acid amide) of the B. virgata leaf extract (BVLE) is an alkaloid compound. Other studies also showed that $B$. virgata compound in the forms of BVI03, NBB (nano-encapsulated BVI03), and NBVG (nano-encapsulated vaginal bioadhesive gels) had antiproliferation activities and the $\mathrm{IC}_{50}$ value of these forms was reported $2.88,59.26$, and $725.46 \mu \mathrm{g} / \mathrm{ml}$ respectively (Lukman et al., 2014). Without extensive studies, there is limited toxicological information available regarding the safety of BLVE owing to its vulnerability. Indonesian authorities are currently concerned with the safety and toxicity of medical and consumable plants (BPOM, 2014).

Presently, no research work confirms whether BLVE creates any toxicological reaction or not. Hence, this study aimed to perform an astute toxicological study with sub-sections to establish a preclinical benchmark necessary for additional establishment by evaluating biochemical, hematological, and histopathological analysis of Wistar rats treated with BVLE. Further, the effect of BVLE on the changes in behavior, skin, body, and organ weight, daily water, and food consumption levels were also taken into consideration.

\section{Materials and Methods}

\subsection{Extraction process of the plants}

B. virgata is a native plant to Malino Town, Gowa City, South Sulawesi Province, Indonesia. Plant leaves samples were collected and a specimen of the plant was identified and deposit at the Indonesian Institute of Sciences (LIPI), Jakarta, Indonesia. After being collected, the leaves were dried and chopped into small pieces. For the ethanol extract preparation, about $150 \mathrm{~g}$ of leaf were macerated for 4 days using $70 \%$ ethanol as a solvent.

\subsection{Characterization of the active isolate as a marker}

The BVI03 was isolated from BVLE as per the method given by Manggau et al (2013). The active isolate of BVLE (BVI03) as a marker was characterized by various physicochemical parameters including UV of wavelength (254 and $366 \mathrm{~nm}$ ), and IR spectra.

\subsection{Animals}

Both genders of adult Wistar rats with an average weight of 150 $\pm 10 \mathrm{~g}$ was used as experimental animals in the current study. These were purchased from Central Rodent Cultivation Centre, Airlangga University, Surabaya. The test animals were randomly divided into two parts, first part used for the acute toxic study has 6 groups ( 3 males and 3 females) while the second part has 8 groups (4 males and 4 females) for sub-acute toxicity tests, each group has five Wistar rats. Polypropylene cages were used to house the rats with the range of temperature and relative humidity of $24-26^{\circ} \mathrm{C}$ and $45-55 \%$ respectively. Water and food pellets having major food nutrients were given to the animals and the day-night time cycle was 12:12 h. They were also given a week to adapt to the new environment conditions before being used for the experiments. The experimental protocol of the animals was approved by the Indonesian committee and it was conducted according to guidelines on animal care from the National Institute of Health.

\subsection{Experimental Design}

For the acute toxicity tests BVLE was administered orally once a day to the rats using a gavage needle and they were evaluated daily for 14 days while for the sub-acute toxicity tests, the rats were given BVLE daily for 28 days; these rats were evaluated on the $14^{\text {th }}$ and $28^{\text {th }}$ day, by following the recommendations of the Indonesian National Agency of Drug and Food Control (Sparingga, 2014). Six groups for acute treatments (3 groups male and female Wistar rats and each group have five organisms) were treated with 2,000 and $5,000 \mathrm{mg} / \mathrm{kg}$ per day dose of BVLE. Meanwhile, eight groups undergoing sub-acute treatments (4 groups male and female Wistar rats and each group have five 
organisms) were treated with 250,500 , and $1,000 \mathrm{mg} / \mathrm{kg}$ of BVLE, respectively (Sparingga, 2014). The solvent was given to the control group for both acute and sub-acute treatments. Observations were carried out every day to ascertain the cause of death and behavioral changes. Weekly body weight analysis was also carried out and the various doses administered to the rats were adjusted weekly to enable the body weight control for the target dose level for all rats. Furthermore, there was a daily examination of the detailed preclinical analysis and measurement of the food and water consumed.

\subsection{Hematology analysis}

On the last day of the sub-acute study, chloroform was used to anesthetize the animals. Plastic test tubes containing EDTA (an anticoagulant) were used to collect the samples. Hematology analyses were carried out using a Hematology Analyzer (Sysmex XS-8000 $i^{\circledR}$, Med Wrench US) with the flow cytometric method. This was used to determine the mean corpuscular hemoglobin $(\mathrm{MCH})$, erythrocyte count (RBC), white blood cells (WBC), the concentration of $\mathrm{MCH}$ (MCHC), distribution width of red blood cells (RDW), the standard deviation of RDW (RDW-SD), coefficient of variation of RDW (RDW-CV), mean corpuscular volume (MCV), hemoglobin, hematocrit, neutrophil, lymphocyte, eosinophil, monocytes, and platelet counts.

\subsection{Biochemical Analysis}

Following the sub-acute toxicity analysis, chloroform was used to anesthetize all the animals used in the study. They subsequently bled through an inferior vena cava. After this, all specimens were gathered in sample tubes, they were placed in a standing position for outright clotting. A total of 15 minutes was used to centrifuge the clotted blood clot at 3000rpm. After that, the serum specimen was kept frozen at $-80^{\circ}$ Celsius. Samples of serum were also used to analyze and determine the total creatinine, serum, AlanineAminotransferase (ALT), and Aspartate-Aminotransferase (AST) concentration using a Humalyzer $3500^{\circledR}$ (Human Germany).

\subsection{Histopathological Observations}

Kidney cells, liver cells, and kidney glomerulus cells were tested with the aid of a microscope after that each one of them had undergone eosin and hematoxylin staining. Dissection of the liver, kidney glomerulus, and kidney was performed to test for signs of toxicity. Any inherent irregularities found on the slides were tagged "mild", "attention" and "definite" in a manner described by Jain et al (2008) and Chi et al. (2014).

\subsection{Statistical analysis}

Kruskal-Wallis one-way and two-way analysis of variance (ANOVA) was applied to subjugate data in the form of Mean \pm
SEM (Standard Error of Mean). A Mann-Whitney-U-test (twotailed) was applied to make inter-group comparisons for responses that produced huge treatment effects in the ANOVA test with $\mathrm{p}<0.05$.

\section{Results}

\subsection{Characterization of the active isolate as a marker}

Characterizations of ethanolic extract were performed with an ultraviolet spectrophotometer by using dichloromethane. The solvent displayed maximum absorption for BVI03 isolate at wavelengths 262, 287, and $369 \mathrm{~nm}$. These wavelengths enable us to detect the presence of conjugated dienes. In addition, the UV spectrum also showed maximum absorption at a wavelength of 285 $\mathrm{nm}$. The absorption peak at wavelength $285 \mathrm{~nm}$ indicates a transition to the state $\pi^{*}$ at the solitary $\mathrm{n}$ electrons in $\mathrm{N}$ atoms occurring at wavelengths greater than $270 \mathrm{~nm}$ (Figure 1).

The infra-red spectrum data of BVI03 isolates at a wavelength of $3372 \mathrm{~cm}^{-1}$ indicates the presence of $\mathrm{OH}$ bound and an amine group. The medium absorption at a wavelength of $927 \mathrm{~cm}^{-1}$ and strong absorption at a wavelength of $1556 \mathrm{~cm}^{-1}$ indicates the possibility of primary amine. Moreover, the absorption at a wavenumber of 2926 $\mathrm{cm}^{-1}$ indicates the presence of an aliphatic $\mathrm{CH}$ group. The presence of a band that absorbs strongly and sharply at a wavelength of $1413 \mathrm{~cm}^{-1}$ indicates the presence of an aromatic group. Strong absorption at $647 \mathrm{~cm}^{-1}, 620 \mathrm{~cm}^{-1}$, and weak for $1129 \mathrm{~cm}^{-1}$ indicates the presence of alkenes (Figure 2).

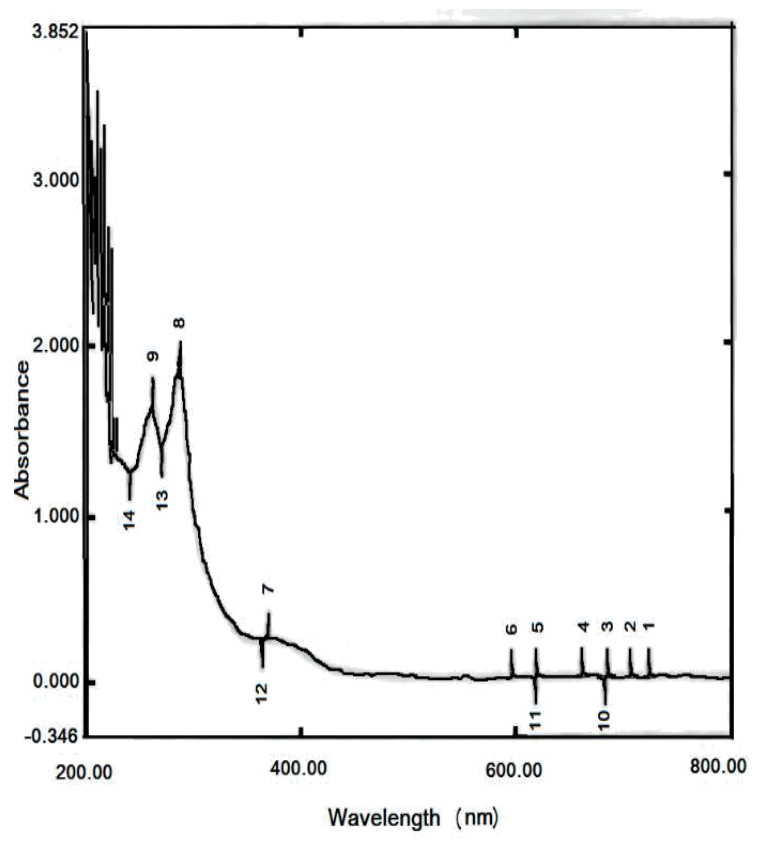

Figure $1 \mathrm{UV}$ spectra data of BVI03 isolate as a marker of BVLE 


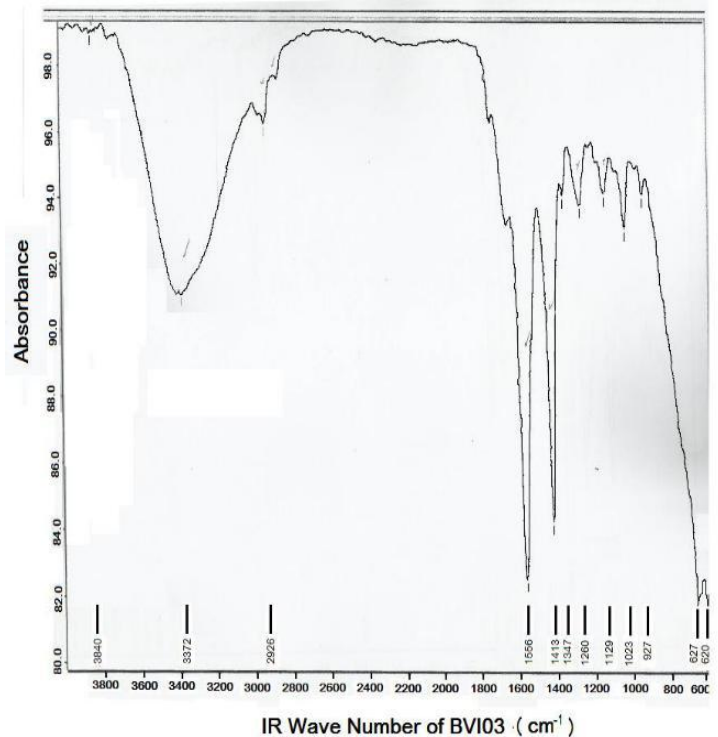

Figure 2 IR spectra data of BVI03 isolate as a marker of BVLE

\subsection{Acute toxicity study}

\subsubsection{Animal observation}

The oral administration of 2000 and $5000 \mathrm{mg} / \mathrm{kg}$ of BVLE did not produce any changes in skin color, behavior, hair loss, defecation, postural abnormalities, breathing, urination, interruption in water or food intake. When assessing their sense of touch and hearing, it was found that the rats were highly sensitive with a lower activity level. Furthermore, no death was observed in any group of BVLE treatment.

\subsubsection{Bodyweight measurement}

The average weight of the rats was measured for 14 successive days. The control group displayed an increase in body weight as compared to the BVLE administered group as displayed in Table 1. Minimum (not significant) changes in body weight were observed in rats which have been administered by $2000 \mathrm{mg} / \mathrm{kg}$ of BVLE.

Table 1 Body weights of rats following acute treatment with BVLE. All treatments are at par and are not significantly different

\begin{tabular}{|c|c|c|c|}
\hline & \multicolumn{3}{|c|}{ Body Weight (g) } \\
\hline & Day 0 & Day 7 & Day 14 \\
\hline \multicolumn{4}{|c|}{ Female } \\
\hline Control & $170 \pm 2.57$ & $171 \pm 1.63$ & $171 \pm 2.74$ \\
\hline $2000 \mathrm{mg} / \mathrm{kg}$ & $171 \pm 1.50$ & $173 \pm 0.76$ & $174 \pm 0.47$ \\
\hline $5000 \mathrm{mg} / \mathrm{kg}$ & $169 \pm 4.47$ & $170 \pm 2.73$ & $170 \pm 2.18$ \\
\hline \multicolumn{4}{|c|}{ Male } \\
\hline Control & $182 \pm 1.43$ & $184 \pm 0.56$ & $186 \pm 4.65$ \\
\hline $2000 \mathrm{mg} / \mathrm{kg}$ & $183 \pm 4.65$ & $186 \pm 3.07$ & $1.85 \pm 3.61$ \\
\hline $5000 \mathrm{mg} / \mathrm{kg}$ & $182 \pm 4.18$ & $184 \pm 3.46$ & $185 \pm 2.54$ \\
\hline
\end{tabular}

Data indicate mean \pm SEM, $n=5$; there was no statistically significant deviation in these data compared with those in the control group, $\mathrm{p}>0.05$

\subsubsection{Intake of food and water}

Calculation of the quantity of water and food intake was measured daily; it can be defined as the difference between the initial quantity, and the total quantity left sub-sequential to 24 hours. The obtained calculated values were depended on the total quantity of food consumed and the average physical critical weight. The obtained data indicated no statistically meaningful difference (CMC; $p>0.05)$. The results showed that the extract didn't affect the body weight (Table 2 ).

Table 2 Food intake of rats in acute toxicity treatment of BVLE

\begin{tabular}{|ccccc|}
\hline & \multicolumn{4}{c}{ Food Intake (grams) } \\
& Sex & Day 0 & Day 7 & Day 14 \\
\hline \multirow{2}{*}{ Control } & Male & $57.56 \pm 2.27$ & $69.38 \pm 0.53$ & $67.42 \pm 0.09$ \\
\cline { 2 - 5 } & Female & $45.65 \pm 2.16$ & $53.26 \pm 1.26$ & $56.37 \pm 3.73$ \\
\hline $\begin{array}{c}2000 \\
\mathrm{mg} / \mathrm{kg}\end{array}$ & Male & $58.73 \pm 1.83$ & $64.27 \pm 0.64$ & $73.65 \pm 1.67$ \\
\cline { 2 - 5 } & Female & $51.15 \pm 3.34$ & $59.43 \pm 2.74$ & $63.24 \pm 1.87$ \\
\hline 5000 & Male & $62.54 \pm 2.35$ & $70.36 \pm 0.29$ & $77.54 \pm 0.04$ \\
\cline { 2 - 5 } $\mathrm{mg} / \mathrm{kg}$ & Female & $46.23 \pm 2.32$ & $54.12 \pm 1.89$ & $64.35 \pm 2.67$ \\
\hline
\end{tabular}

Data indicate mean \pm SEM, $\mathrm{n}=5$; There was no statistically significant deviation in these data compared with those in the control group, $\mathrm{p}>0.05$

\subsubsection{Organ weight}

On the $14^{\text {th }}$ day of treatment with BVLE, the livers and kidneys were weighed on an electronic balance and relative organ weights of the treated groups were compared to the negative control. Using Kruskal-Wallis analysis, the nonsignificant difference ( $p>0.05$ ) was reported in BVLE treated females when compared with the untreated control (Table 3). Increasing the dose of BVLE affected the degree of hydropic degeneration in the female liver and renal cells. For the liver cells of the $2000 \mathrm{mg} / \mathrm{kg}$ treatment group, the average percentage of hydropic degeneration was $39.93 \%$, which is categorized as light damage $(0-49 \%)$ while $5000 \mathrm{mg} / \mathrm{kg}$ treatment $(52.39 \%)$ is categorized as moderate $(50 \%-74 \%)$, while hydropic degeneration in the male liver and renal cells didn't occur after treatment with BVLE. Table 4 showed non-significant enlargement of mice renal glomerular after BVLE treatment dose of 2000 and $5000 \mathrm{mg} / \mathrm{kg}$.

\subsubsection{Histology of liver, renal and renal glomerular after} treatment of BVLE

Histological tests of the organs indicated that acute BVLE treatment by an oral administration of up to $2000 \mathrm{mg} / \mathrm{kg}$ yields mild hydropic degeneration. At a dose of $5000 \mathrm{mg} / \mathrm{kg}$, moderate hydropic degeneration appeared as compared with the control group (Figure 3 and 4, Table 3). Hydropic degeneration is characterized by watercontaining vacuoles in the cytoplasm, cloudy, pale, and the nucleus 
is pushed to the edge. Increasing the dose of BVLE affected the degree of hydropic degeneration in the female liver and renal cells. For renal cells in the $2000 \mathrm{mg} / \mathrm{kg}$ treatment group, the average percent of hydropic degeneration was $39.93 \%$, characterized by water containing vacuoles in the cytoplasm, so that the renal cells looked paler than the normal renal cells, which is categorized as light damage (hydropic degeneration $<50 \%$ ). Whereas, the treatment of $5000 \mathrm{mg} / \mathrm{kg}(52.39 \%)$ BVLE showed water-containing vacuoles in the cytoplasm, cloudy, pale and the nucleus is pushed to the edge, which is categorized as moderate (hydropic degeneration $<75 \%$ ). In contrast, the hydropic degeneration in male renal cells didn't occur after treatment with BVLE.

\subsection{Sub-acute toxicity study}

\subsubsection{Body weights and food intake}

The physical weights and food intake of the rats were not altered by the sub-acute doses of BVLE administration. As shown in table 5 and 6, no significant changes were reported in both parameters i.e. body weights and food intake of both genders of Wistar rats before and after treatment with BVLE even after the 28th day of treatment. The obtained data indicated no statistically meaningful difference, $p>0.05$. The results showed that the extract didn't affect the body weight and food intake.

Table 3 Histology and weight of female and male Wistar rat liver and renal cells after the acute treatment of BVLE

\begin{tabular}{|c|c|c|c|c|c|c|}
\hline \multirow[b]{2}{*}{ Treatment } & \multicolumn{3}{|c|}{ Liver } & \multicolumn{3}{|c|}{ Renal } \\
\hline & Weight & $\begin{array}{c}\text { Hydropic } \\
\text { Degeneration (\%) }\end{array}$ & Degree & Weight & Hydropic Degeneration (\%) & Degree \\
\hline Control (female) & $3.51 \pm 0.03$ & $20.72 \pm 3.54$ & - & $0.61 \pm 0.01$ & $19.65 \pm 0.50$ & - \\
\hline $2000 \mathrm{mg} / \mathrm{kg}$ & $3.65 \pm 0.02$ & $39.97 \pm 5.89$ & + & $0.69 \pm 0.002$ & $34.02 \pm 3.94$ & + \\
\hline $5000 \mathrm{mg} / \mathrm{kg}$ & $3.84 \pm 0.02$ & $52.39 \pm 8.28$ & ++ & $0.73 \pm 0.002$ & $47.13 \pm 10.90$ & ++ \\
\hline Control (male) & $3.56 \pm 0.01$ & $21.64 \pm 4.40$ & - & $0.63 \pm 0.003$ & $20.86 \pm 3.34$ & - \\
\hline $2000 \mathrm{mg} / \mathrm{kg}$ & $3.75 \pm 0.02$ & $22.97 \pm 3.89$ & - & $0.65 \pm 0.006$ & $21.02 \pm 3.54$ & - \\
\hline $5000 \mathrm{mg} / \mathrm{kg}$ & $3.79 \pm 0.05$ & $29.39 \pm 6.29$ & + & $0.78 \pm 0.007$ & $28.15 \pm 10.90$ & + \\
\hline
\end{tabular}

Values are expressed as mean $\pm \mathrm{SEM} ; \mathrm{n}=5$; significantly different from control group; $\mathrm{p}>0.05$; normal $(0-25 \%) ;+-$ mild $(25-49 \%) ;++-$ moderate $(50-74 \%) ;+++-$ severe $(75-100 \%)$ as per Ghufron (2011)

Table 4 Histology of renal glomerular after single-dose treatment of BVLE and CMC as control

\begin{tabular}{|cccc|}
\hline No. & Treatment & Enlargement of renal glomerular $(\%)$ & Degree \\
\hline 1 & Control & $22.8667 \pm 3.33933$ & - \\
\hline 2 & $2000 \mathrm{mg} / \mathrm{kg}$ & $22.3867 \pm 6.20238$ & - \\
\hline 3 & $5000 \mathrm{mg} / \mathrm{kg}$ & $28.2133 \pm 4.68740$ & + \\
\hline
\end{tabular}

Data indicates mean \pm SEM; normal (0-25\%); + - mild (25-49\%); ++ - moderate (50-74\%); +++ - severe (75-100\%) as per Ghufron (2011)

Table 5 Body weights of rats following sub-acute treatment with BVLE

\begin{tabular}{|c|c|c|c|c|c|}
\hline \multirow[b]{2}{*}{ Treatment } & \multicolumn{5}{|c|}{ Bodyweight (g) } \\
\hline & Day 0 & Day 7 & Day 14 & Day 21 & Day 28 \\
\hline \multicolumn{6}{|c|}{ Female } \\
\hline Control & $162 \pm 4.47$ & $165 \pm 3.54$ & $167 \pm 2.74$ & $167 \pm 2.86$ & $171 \pm 2.23$ \\
\hline $250 \mathrm{mg} / \mathrm{kg}$ & $162 \pm 3.56$ & $167 \pm 2.73$ & $162 \pm 4.47$ & $167 \pm 2.73$ & $172 \pm 2.74$ \\
\hline $500 \mathrm{mg} / \mathrm{kg}$ & $162 \pm 4.47$ & $167 \pm 3.47$ & $166 \pm 4.18$ & $168 \pm 2.74$ & $171 \pm 2.24$ \\
\hline $1000 \mathrm{mg} / \mathrm{kg}$ & $163 \pm 4.47$ & $168 \pm 2.73$ & $166 \pm 4.18$ & $167 \pm 2.74$ & $172 \pm 2.74$ \\
\hline \multicolumn{6}{|c|}{ Male } \\
\hline Control & $186 \pm 3.53$ & $188 \pm 4.56$ & $192 \pm 3.71$ & $197 \pm 2.74$ & $198 \pm 4.16$ \\
\hline $250 \mathrm{mg} / \mathrm{kg}$ & $187 \pm 4.37$ & $190 \pm 3.07$ & $194 \pm 4.61$ & $197 \pm 5.58$ & $202 \pm 5.70$ \\
\hline $500 \mathrm{mg} / \mathrm{kg}$ & $186 \pm 4.18$ & $189 \pm 6.52$ & $195 \pm 3.54$ & $193 \pm 5.71$ & $199 \pm 5.41$ \\
\hline $1000 \mathrm{mg} / \mathrm{kg}$ & $190 \pm 5.09$ & $193 \pm 4.70$ & $195 \pm 4.18$ & $193 \pm 2.24$ & $200 \pm 4.18$ \\
\hline
\end{tabular}

Data indicate mean \pm SEM; $n=5$; There was no statistically significant deviation in these data compared with those in the control group, $\mathrm{p}>0.05$

Journal of Experimental Biology and Agricultural Sciences http://www.jebas.org 
Table 6 Food intake for single rat following oral administration of the ethanol extract from BVLE

\begin{tabular}{|ccccccc|}
\hline \multirow{2}{*}{ Treatment } & & \multicolumn{3}{c|}{ Food Intake (g) } & Day 21 & Day 28 \\
\hline \multirow{2}{*}{ Control } & Sex & Day 7 & Day 14 & $74.21 \pm 0.899$ & $83.14 \pm 1.07$ & $82.12 \pm 1.74$ \\
\cline { 2 - 6 } & Male & $64.12 \pm 1.25$ & $62.71 \pm 1.18$ & $62.03 \pm 1.17$ & $67.85 \pm 0.73$ \\
\hline \multirow{2}{*}{$250 \mathrm{mg} / \mathrm{Kg}$} & Female & $49.41 \pm 1.13$ & $74.42 \pm 0.64$ & $81.28 \pm 0.96$ & $83.71 \pm 0.68$ \\
\cline { 2 - 6 } & Male & $64.71 \pm 1.08$ & $63 \pm 1.02$ & $58.28 \pm 0.68$ & $68.42 \pm 0.57$ \\
\hline \multirow{2}{*}{$500 \mathrm{mg} / \mathrm{Kg}$} & Female & $49.14 \pm 1.03$ & $73.42 \pm 1.23$ & $80.36 \pm 1.24$ & $83.57 \pm 0.78$ \\
\cline { 2 - 6 } & Male & $64.71 \pm 1.01$ & $60.01 \pm 2.34$ & $60.15 \pm 3.14$ & $68.42 \pm 0.52$ \\
\hline \multirow{2}{*}{$1000 \mathrm{mg} / \mathrm{Kg}$} & Female & $49.14 \pm 1.01$ & $74.85 \pm 1.42$ & $80.24 \pm 3.27$ & $81.42 \pm 1.42$ \\
\cline { 2 - 6 } & Male & $65.85 \pm 1.10$ & $60.34 \pm 3.24$ & $60.17 \pm 2.43$ & $68.42 \pm 0.36$ \\
\hline
\end{tabular}

Data indicate mean \pm SEM; $n=5$; There was no statistically significant deviation in these data compared with those in the control group, $\mathrm{p}>0.05$

a.

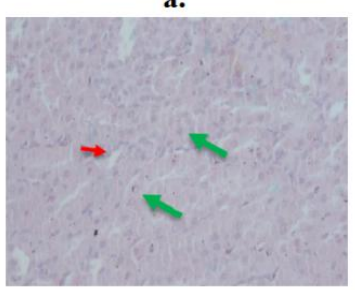

c.

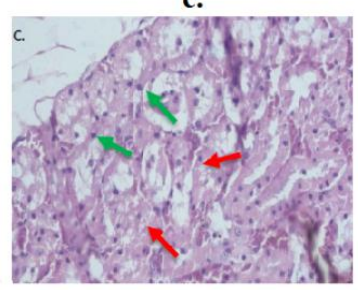

e.

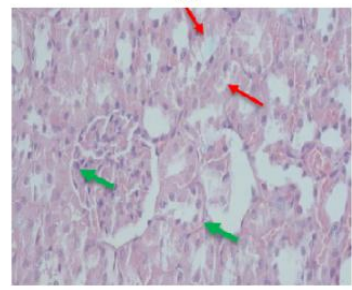

Figure 3 Renal histology of male and female in white rats control group (CMC) in males (a); and females (b); after a single (acute) dose of BVLE of $2000 \mathrm{mg} / \mathrm{kg}$ for males (c) and females (d); after administration of $5000 \mathrm{mg} / \mathrm{kg}$ for males in (e) and females in (f) (HE. 400x). Description: green arrow: normal cells, red arrow: hydropic degeneration

\subsubsection{Biochemical Analysis}

After the administration of BVLE for the pre-treatment of AST (Figure 5), ALT (Figure 6), ureum (Figure 7), and creatinine levels (Figure 8) no significant changes were found after the $28^{\text {th }}$ day of treatment compared to the control group. a.

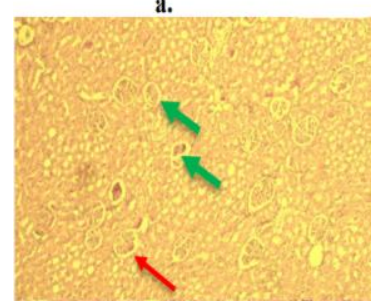

c.

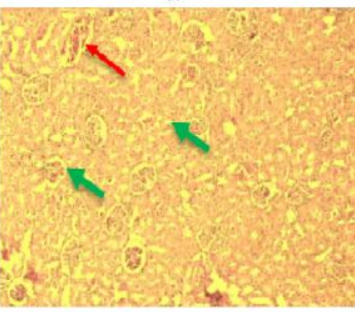

e.
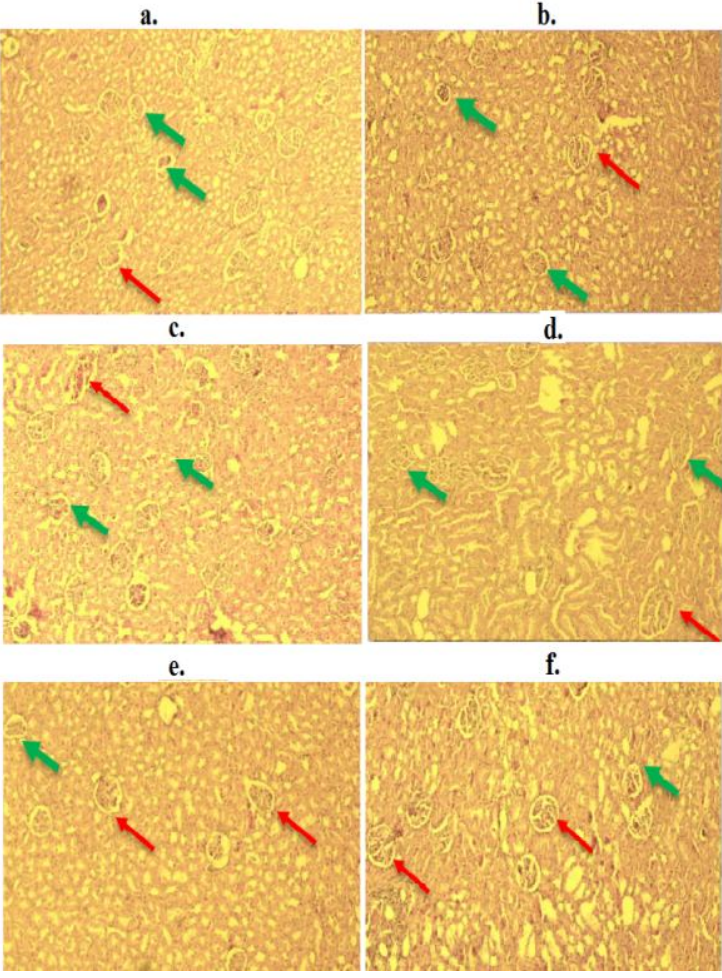

d.

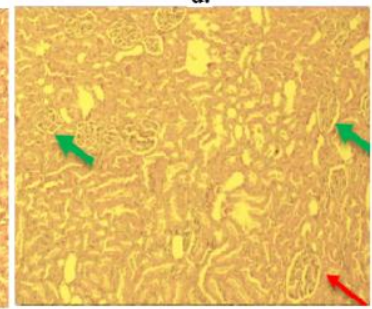

f.

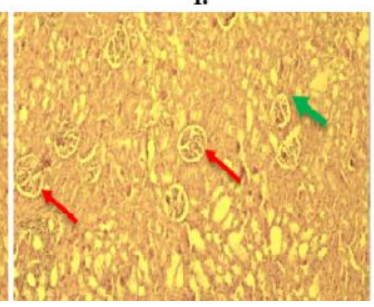

Figure 4 Renal glomerular histology of male and female white rat in control group (CMC) males (a) and females (b): after a single (acute) dose of BVLE of $2000 \mathrm{mg} / \mathrm{kg}$ for males (c) and females (d); after administration of $5000 \mathrm{mg} / \mathrm{kg}$ for males in (e) and females in (f) (HE. 400x). Description: green arrow: normal cells, red arrow: hydropic degeneration

\subsubsection{Hematological Analysis}

Results presented in tables 7-10 revealed that the hematological profiles of the control and BVLE subacute treated groups are not significantly different. This suggested that BVLE treatment didn't have any toxic effect on the hematological parameters. 


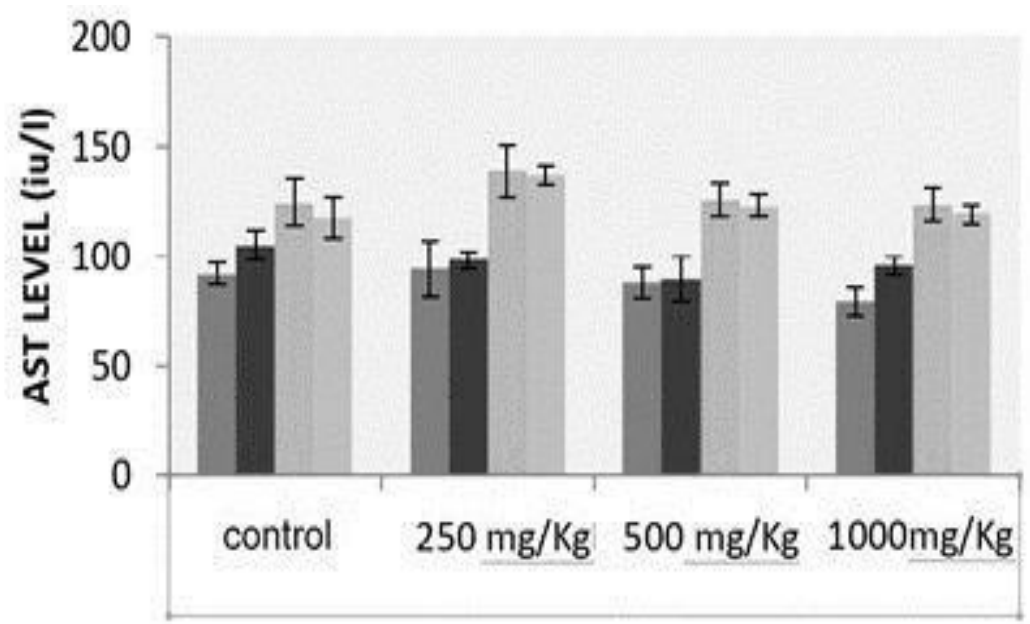

male rats before treatment

female rats before treatment

male rats. after treatment

female rats after treatment

Figure 5 AST levels before and after sub-acute administration of BVLE for 28 days. Data: mean \pm SEM; $n=5$ ( 5 males, 5 females), $p>0.05$.

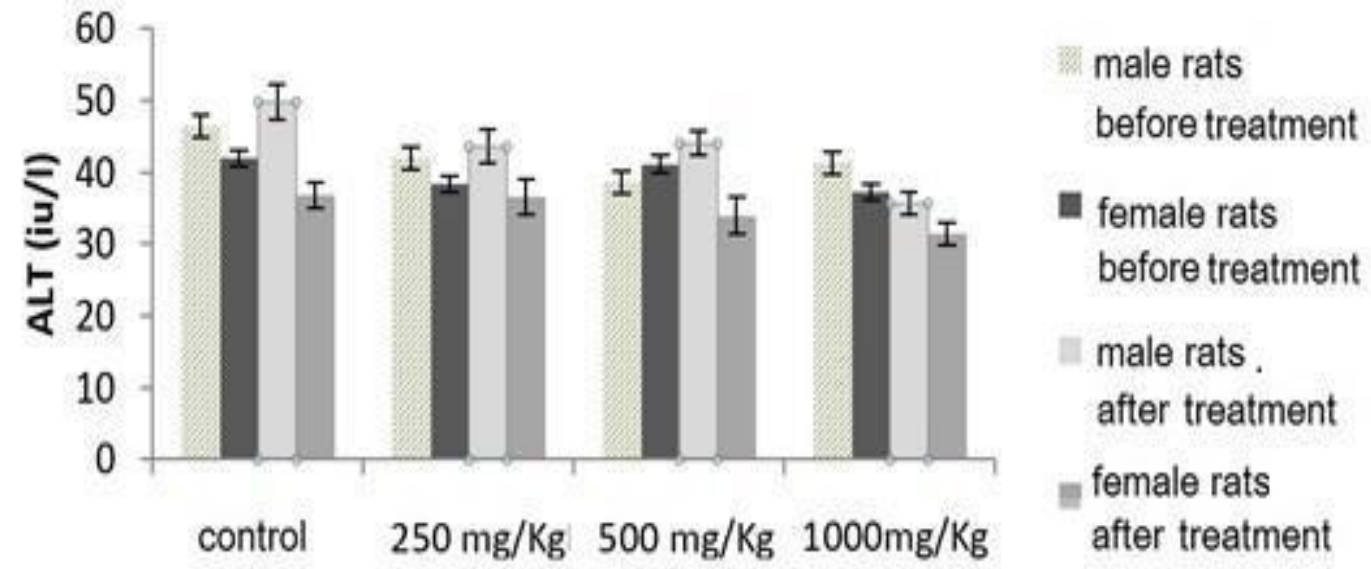

Figure 6 ALT levels before and after sub-acute administration of BVLE for 28 days. Data: mean \pm SEM; $\mathrm{n}=5$ ( 5 males, 5 females), $\mathrm{p}>0.05$.

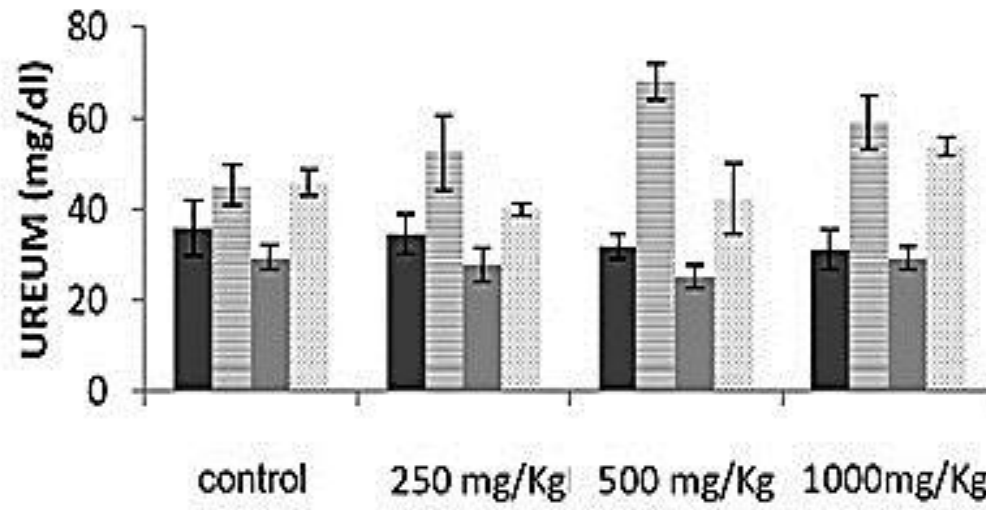

日 male rats before treatment

플 female rats before treatment

$\square$ male rats. after treatment

E female rats after treatment

Figure 7 Ureum levels before and after sub-acute administration of BVLE for 28 days. Data: mean \pm SEM; $n=5$ ( 5 males, 5 females); $\mathrm{p}>0.05$. 


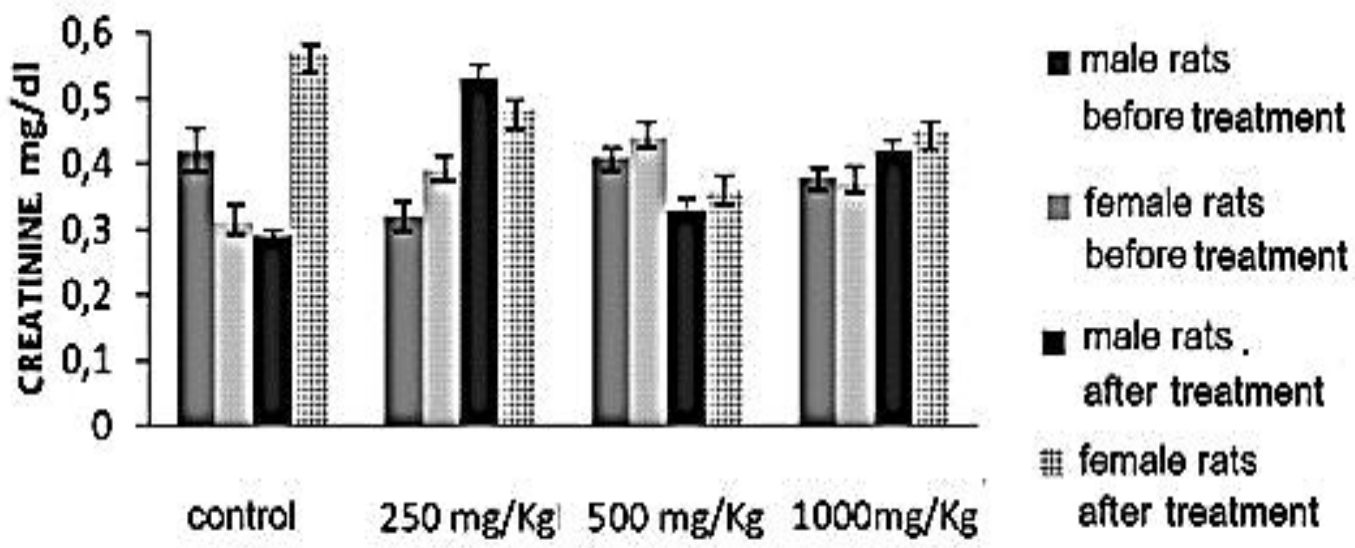

Figure 8 Creatinine levels before and after sub-acute administration of $B$. virgata leaves extract for 28 days. Data: mean \pm SEM; $\mathrm{n}=5$ (5 males, 5 females), $\mathrm{p}>0.05$

Table 7 Hematology analysis data of rat erythrocytes following treatment with BVLE

\begin{tabular}{|cccccc|}
\hline \multirow{2}{*}{$\begin{array}{c}\text { Hematology } \\
\text { Erythrocyte } \\
\left(\mathrm{x} 10^{6} / \mu \mathrm{l}\right)\end{array}$} & Sex & Control & $250 \mathrm{mg} / \mathrm{kg}$ & $500 \mathrm{mg} / \mathrm{kg}$ & $1000 \mathrm{mg} / \mathrm{kg}$ \\
\cline { 2 - 6 } & Male & $8.56 \pm 0.33$ & $8.17 \pm 0.29$ & $7.13 \pm 0.15$ & $6.90 \pm 0.99$ \\
\hline \multirow{2}{*}{ MCV $(\mathrm{fl})$} & Female & $6.70 \pm 0.69$ & $6.80 \pm 0.47$ & $7.60 \pm 0.24$ & $7.40 \pm 0.24$ \\
\cline { 2 - 6 } & Male & $49.40 \pm 0.77$ & $48.43 \pm 1.07$ & $52.33 \pm 1.02$ & $53.26 \pm 2.86$ \\
\hline \multirow{2}{*}{ MCH $(\mathrm{pg})$} & Female & $56.50 \pm 2.91$ & $56.80 \pm 3.83$ & $51.46 \pm 0.66$ & $54.16 \pm 0.26$ \\
\hline \multirow{2}{*}{ MCHC $(\mathrm{g} / \mathrm{dl})$} & Male & $17.60 \pm 0.15$ & $17.16 \pm 0.26$ & $18.00 \pm 0.30$ & $17.73 \pm 0.17$ \\
\cline { 2 - 6 } & Female & $18.80 \pm 0.17$ & $19.50 \pm 0.90$ & $18.30 \pm 0.20$ & $18.96 \pm 0.08$ \\
\hline
\end{tabular}

Data indicated are mean of five replicates \pm SEM; There was no statistically significant deviation in these data compared with those in the control group, $\mathrm{p}>0.05$

Table 8 Hematology analysis data of rat leucocytes following treatment with BVLE

\begin{tabular}{|ccccccc|}
\hline \multirow{2}{*}{ Hematology Profile } & Sex & \multicolumn{5}{c|}{ Treatments } \\
& & Control & $250 \mathrm{mg} / \mathrm{kg}$ & $500 \mathrm{mg} / \mathrm{kg}$ & $1000 \mathrm{mg} / \mathrm{kg}$ \\
\hline \multirow{2}{*}{ Leucocyte $\left(\mathrm{x} 10^{3} / \mu \mathrm{l}\right)$} & Male & $22.88 \pm 3.52$ & $22.90 \pm 1.26$ & $23.90 \pm 0.49$ & $24.56 \pm 4.14$ \\
\cline { 2 - 6 } & Female & $22.76 \pm 2.97$ & $14.46 \pm 2.30$ & $16.79 \pm 1.90$ & $14.58 \pm 1.79$ \\
\hline \multirow{2}{*}{ Lymphocyte $(\%)$} & Male & $15.76 \pm 1.07$ & $29.33 \pm 1.20$ & $23.7 \pm 2.07$ & $22.1 \pm 11.75$ \\
\cline { 2 - 6 } & Female & $11.26 \pm 0.98$ & $18.66 \pm 2.19$ & $13.46 \pm 1.47$ & $17.33 \pm 2.45$ \\
\hline \multirow{2}{*}{ Monocyte $(\%)$} & Male & $43.6 \pm 2.99$ & $55.73 \pm 0.88$ & $45.06 \pm 2.74$ & $37.03 \pm 19.7$ \\
\cline { 2 - 6 } & Female & $49.93 \pm 2.00$ & $61.93 \pm 1.35$ & $64.7 \pm 2.00$ & $51.53 \pm 2.77$ \\
\hline \multirow{2}{*}{ Eosinophil $(\%)$} & Male & $6.86 \pm 0.55$ & $5.76 \pm 1.44$ & $5.9 \pm 0.95$ & $7.83 \pm 1.21$ \\
\cline { 2 - 6 } & Female & $3.76 \pm 1.93$ & $5.96 \pm 0.88$ & $8.56 \pm 0.811$ & $6.7 \pm 0.43$ \\
\hline
\end{tabular}

Data indicated are mean of five replicates \pm SEM; There was no statistically significant deviation in these data compared with those in the control group, $\mathrm{p}>0.05$

Journal of Experimental Biology and Agricultural Sciences http://www.jebas.org 
Table 9 Hematology analysis data of rat thrombocytes following treatment with BVLE

\begin{tabular}{|cccccc}
\hline \multirow{2}{*}{ Hematology Profile } & \multirow{2}{*}{ Sex } & \multicolumn{4}{c}{ Treatments } \\
& & Control & $250 \mathrm{mg} / \mathrm{kg}$ & $500 \mathrm{mg} / \mathrm{kg}$ & $1,000 \mathrm{mg} / \mathrm{kg}$ \\
\hline \multirow{2}{*}{ Thrombocyte $(\mathrm{X} \mathrm{10} / \mu \mathrm{L})$} & Male & $1122.6 \pm 53.07$ & $1099 \pm 58.62$ & $1129.6 \pm 63.18$ & $1229 \pm 71.27$ \\
\cline { 2 - 6 } & Female & $805.33 \pm 2.16$ & $873.33 \pm 2.81$ & $1112.3 \pm 58.32$ & $1196 \pm 1.08$ \\
\hline \multirow{2}{*}{ MPV ( fl $)$} & Male & $7.66 \pm 0.12$ & $7.23 \pm 0.08$ & $7.76 \pm 0.03$ & $7.7 \pm 0.05$ \\
\cline { 2 - 6 } & Female & $8.03 \pm 0.47$ & $7.76 \pm 0.29$ & $7.56 \pm 0.17$ & $7.5 \pm 0.15$ \\
\hline \multirow{2}{*}{ PDW ( fl ) } & Male & $7.93 \pm 0.17$ & $7.63 \pm 0.03$ & $8.31 \pm 0.33$ & $8.33 \pm 0.27$ \\
\cline { 2 - 6 } & Female & $8.9 \pm 0.77$ & $8.33 \pm 0.32$ & $8.06 \pm 0.14$ & $8 \pm 0.25$ \\
\hline \multirow{2}{*}{ P-LCR (\%) } & Male & $7.66 \pm 0.90$ & $6.2 \pm 0.80$ & $9.03 \pm 0.51$ & $8.9 \pm 0.24$ \\
\cline { 2 - 6 } & Female & $11.3 \pm 3.19$ & $9.13 \pm 1.70$ & $8.23 \pm 1.47$ & $7.36 \pm 0.97$ \\
\hline
\end{tabular}

Data indicated are mean of five replicates \pm SEM; There was no statistically significant deviation in these data compared with those in the control group, $\mathrm{p}>0.05$

Table 10 Hematology analysis data of rat hemoglobin, hematocrit, RDW-SD, and RDW-CV following treatment with BVLE

\begin{tabular}{|cccccc|}
\hline \multirow{2}{*}{ Hematology Profile } & \multirow{2}{*}{ Sex } & \multicolumn{5}{c|}{ Treatments } \\
\cline { 2 - 6 } & & Control & $250 \mathrm{mg} / \mathrm{kg}$ & $500 \mathrm{mg} / \mathrm{kg}$ & $1,000 \mathrm{mg} / \mathrm{kg}$ \\
\hline \multirow{2}{*}{ Hemoglobin $(\mathrm{g} / \mathrm{dl})$} & Male & $15.06 \pm 0.57$ & $14.01 \pm 0.28$ & $12.83 \pm 0.14$ & $12.26 \pm 1.81$ \\
\cline { 2 - 6 } & Female & $12.56 \pm 1.18$ & $13.23 \pm 0.76$ & $13.9 \pm 0.32$ & $13.53 \pm 0.28$ \\
\hline \multirow{2}{*}{ Hematocrit $(\%)$} & Male & $42.26 \pm 1.02$ & $39.50 \pm 0.62$ & $37.23 \pm 0.33$ & $36.26 \pm 3.70$ \\
\cline { 2 - 6 } & Female & $37.46 \pm 2.17$ & $38.46 \pm 1.94$ & $40.03 \pm 0.71$ & $38.66 \pm 0.71$ \\
\hline \multirow{2}{*}{ RDW-SD (fl) } & Male & $29.56 \pm 1.18$ & $29.90 \pm 0.66$ & $36.5 \pm 3.72$ & $36.56 \pm 4.76$ \\
\cline { 2 - 6 } & Female & $36.40 \pm 8.06$ & $32.23 \pm 2.77$ & $30.33 \pm 1.16$ & $29.06 \pm 0.38$ \\
\hline \multirow{2}{*}{ RDW-CV $(\%)$} & Male & $20.06 \pm 0.80$ & $20.20 \pm 0.69$ & $21.43 \pm 1.31$ & $21.33 \pm 0.92$ \\
\cline { 2 - 6 } & Female & $19.93 \pm 3.14$ & $17.80 \pm 0.98$ & $18.76 \pm 0.29$ & $17.13 \pm 0.32$ \\
\hline
\end{tabular}

Data indicated are mean of five replicates \pm SEM; There was no statistically significant deviation in these data compared with those in the control group, $\mathrm{p}>0.05$

\section{Discussion and Conclusion}

The threat of cervical cancer is still a serious problem for women's health. Anti-cervical cancer drugs can cure cancer by killing cells. Unfortunately, these drugs also destroy normal cells, which might cause some uncomfortable side effects (Meegan \& O'Boyle, 2019), and these side effects depend on the type of the drugs. The development of an effective chemotherapeutics agent with no toxic effects is urgently needed. Active ingredients obtained from plant sources can be an alternative to these anticancer drugs. Previous studies showed that the anti-cancer effect of the isolated active compound (BV103) in human cervical cancer, HeLa cells of BVLE was mediated by the activation of caspase 3 and $p 53$ protein (Manggau et al., 2012). Recently the putative effect of BVLE alkaloid compound 10-(6,6dihydroxyhexyl)-2,3,6-trimethoxyphenanthrene-9-carboxamide has been established as a potent anticancer agent (Manggau et al., 2018).
There are still no studies that establish the safe doses and possible toxicological reactions to BVLE which has been utilized as traditional medicine by the people of Makassar to cure inflammation and cancer. Therefore, the recent research was conducted using an in vivo model to study the toxicity of BVLE acutely and sub-acutely.

Intense administration of BVLE in rats @ 5,000 mg/kg doses led to neither mortality nor signs of toxicity. This suggested that an $\mathrm{LD}_{50}$ of BVLE per oral administration in rats is higher than 5,000 $\mathrm{mg} / \mathrm{kg}$. Since substances with $\mathrm{LD}_{50}$ larger than $5,000 \mathrm{mg} / \mathrm{kg}$ by oral administration are non-toxic (Kennedy et al., 1986), so the acute administration of BVLE is non-toxic. The treatment group of $2,000 \mathrm{mg} / \mathrm{kg}$ showed some degree of hydropic degeneration, and it was reported $39.97 \%$ for liver cells and $34.02 \%$ for renal cells, that was categorized as "mild damage" $(<50 \%)$ but such hydropic degeneration in hepatocyte cells was also reported in the control 
group (Figure 1a). Further, the group treated with 5,000 mg/kg also showed the presence of hydropic degeneration and it was reported $52.39 \%$ for liver cells and $47.13 \%$ for renal cells that descriptively categorized as "moderate damage" (Figure 5c).

The process of hepatocyte damage starts from hydropic degeneration. Hydropic degeneration is mild and reversible damage. It can be a response to infection or exposure to toxicity. This toxicity causes a disruption in the mitochondrial organelle that produces ATP required for the gating of the cellular sodium via cell membrane $\left(\mathrm{Na}^{+}\right)$pumps. If mitochondrial organelle does not produce ATP, there will be no osmotic potential increase in cells and water will be attracted into the cells. Sodium ions $\left(\mathrm{Na}^{+}\right)$ attract water, so water enters the cell. Vacuoles containing water are clear and small in the cytoplasm. These unite to form larger vacuoles that occupy the cytoplasm and cover cell nuclei and cause cell swelling.

Furthermore, in sub-acute treatment i.e. 250,500 and $1,000 \mathrm{mg} / \mathrm{kg}$ doses of BVLE also didn't show any deaths or toxic symptoms even after 28 days of daily administration. Further, physical weight, as well as food intake, was unaltered during this period. The doses of BVLE are ascertained to be approximately 50 (acute) and 15 (sub-acute) times stronger than other species of $B$. virgata, such as B.nivea var. Tenacissima and B. nivea var. nivea, used as a hepatoprotective against liver injury triggered by carbon tetrachloride $\left(\mathrm{CCl}_{4}\right)$ (Chun-Ching et al., 1998). Other research has been illustrated that daily extract administration of $B$. nivea of $32 \mathrm{~g} / \mathrm{kg}$ does not lead to embryo or maternal toxicity in mice, even though it is likely to cause cytotoxicity in cultured ESCs when being administered in large doses. B. nivea is another species of $B$. virgate that is commonly given to cure organ failure medically (Tian et al., 2011).

Treatment with BVLE didn't show any observable changes in the biochemical parameters. The AST levels also did not differ from normally measured levels (Hall Robert, 1992; Qili et al., 2017). All standard hematological parameters used were within the normal reference range. Normal values of erythrocytes and leucocytes also did not differ from normally measured levels (Harkness et al., 2010). Compared to other studies platelet profile and platelet index levels for all sample groups are still in the normal range (Qili et al, 2017).

The study of effective chemotherapeutics with no toxic effects is urgently needed. This study showed no toxic effect of BVLE acutely and sub-acutely in the tested animals. Consistent with our previous study, the anti-cancer effect of isolated active compound (BVI03) in human cervical cancer HeLa cells of BVLE was mediated by activation of caspase 3 and p53 protein (Manggau et al, 2009; Gufron, 2011; Mohamed et al., 2011).
Further, no significant toxicity was reported in the biochemical, behavioral, histological, and hematological parameters of Wistar rats after the acute and sub-acute administration of BVLE. However, moderate hydropic degeneration can be seen in rat livers following acute administration of $5,000 \mathrm{mg} / \mathrm{kg}$ BLVE. Further studies are needed, namely the mechanism of hydropic degeneration, measurement of microsomal enzyme induction parameters, and studies of chronic treatment effects. Therefore, BVLE fulfills a preclinical criterion that is necessary for being a clinically useful extract for cervical cancer drugs.

\section{Acknowledgment}

The research was funded by a grant from the WCP-B Program (Grant Number 123.48/D2.3/KP/2018), Ministry of Research, Technology and Higher Education, Republic of Indonesia. The authors wish to thank Dr. Guy Yealland for proofreading the manuscript. The authors declare that there are no conflicts of interest.

\section{Conflict of Interest- Nil}

\section{References}

Badan Pengawas Obatdan Makanan Republik Indonesia (2014) Pedoman Uji Toksisitas Nonklinik Secara In Vivo. Edisi ke-7. BPOM, Indonesia

Chi MH, Hui RC, Yang CH, Lin JY, Lin YT, Ho HC, Chung WH, Kuo TT ( 2014) Histopathological analysis and clinical correlation of drug reaction with eosinophilia and systemic symptoms (DRESS). Journal of British Dermatology 170 (4): 866-873.

Chun-Ching L, Ming-Hong Y, Tsae-shiuan L, Jer-Min L (1998) Evaluation of the hepatoprotective and antioxidant activity of Boehmeria nivea var nivea and B. nivea var tenacissima. Journal of Ethnopharmacology 60(1): 9-17.

Gufron M (2011) Gambaran Struktur Histologi Hepar dan Renal Mencit Setelah Pemberian Perlakuan Infus Akar Rimpang Jahe (Zingiber officinale) dengan Dosis Bertingkat. Jurnal Kedokteran Yarsi. 11: 15-20.

Hall Robert L (1992) Clinical pathology of laboratory animals. In: Andress JM (Ed.), Animal Models in Toxicology. New York. Marcell Dekker Inc. Pp. 791.

Harkness JE, Turner PV, Van de woude S (2010) Harkness and Wagner's Biology and Medicine of Rabbits and Rodents. $5^{\text {th }}$ ed. Ames: Willey-Blackwell Publication.

Jain M, Soni L, Deb A, Jain SP, Rout VB, Gupta KL, Krishna (2008) Antioxidant and hepatoprotective activity of ethanolic and 
aqueous extract of Momordica dioica Roxb leaves. Journal of Ethnopharmacology 15: 61-66.

Kennedy GL, Ferenz RL, Burgess BA (1986) Estimation of acute oral toxicity in rats by determination of the approximate lethal dose rather than the LD50. Journal of Applied Toxicology 6(3): 145148.

Lukman M, Rusdi M, Hatta M, Rahman L, Subehan, Manggau M (2014) Anti proliferation activity of Nano encapsulated bioadhesive vaginal gel of isolated active Compound (BVI03) from Boehmeria virgata (Forst) Guill leaves against human cancer cervix Hela cells. International Journal of Pharmaceutical Science Research 6: 836-839.

Manggau M, Andriani F, Mufidah, Nurdin WB, Yulianti R, Usmar, Sutriadi S (2018) The in vitro study of the Alkaloid AntiCancer Compound from Makassar Medicinal Plants Boehmeria virgata Linn. International Journal of Pharmaceutical Science Review and Research 49(1): 77-81.

Manggau M, Hasan H, Wahyudin E, Haryono K, Mufidah, Lukman (2011) Efek Farmakologi Tanaman Antikanker yang Digunakan oleh Masyarakat Sulawesi Selatan. Balitbangda Sulawesi Selatan. ISBN 9786028400558.

Manggau M, Lukman, Rusdi M, Hatta M, Sinrang AW, Subehan (2013) Effect of an Isolated Active Compound (BVI03) of Boehmeria virgata (Forst) Guill leaves on Anti-Proliferation in Human Cancer Cervix HeLa Cells through Activation of Caspase 3 and p53 Protein. Tropical Medicine \& Surgery 1(3): 1-4.

Manggau M, Mufidah, Lindequist U (2009) Antiproliferation Against Human Bladder Cancer 5637 Cell Line and Antioxidant
Activity of Various Plant Extracts. The Indonesian Journal of Natural Products 6: 247-250.

Meegan MJ, O’Boyle NM (2019) Editorial of Special Issue of “Anticancer Drugs". Pharmaceuticals 12(3): 134-140. DOI: https://doi.org/10.3390/ph12030134.

Mohamed EAH, Lim CP, Ebrika OS, Asmawi MZ, Sadikun A, Yam MF (2011) Toxicity evaluation of a standardised 50\% ethanolic extract of Orthosiphon stamineus. Journal of Ethnopharmacology 133: 358-363.

Qili H, Guoming S, Keliang L, Fangcheng Z, Yong J, Jun G, Lida L, Zhongren J, Minwu J, Huiping X (2017) Sex-specific reference intervals of hematologic and biochemical analytes in SpragueDawley rats using the nonparametric rank percentile method. PLoS ONE 12(12):e0189837. doi: 10.1371/journal.pone.0189837.

Sparingga RA (2014) BPOM-RI (Indonesian National Agency of Drug and Food Control, Republic of Indonesia), Non-Clinical In Vivo Toxicity Test Guidelines and Regulation, Available at http://jdih.pom.go.id accessed 13 December 2018.

Tian XY, Xu M, Deng B, Leung KS, Cheng KF, Zhao ZZ, Zhang SP, Yang ZJ, Deng PX, Xu DY, Xu XP, Koo I, Wong M (2011) The effects of Boehmeria nivea (L.) Gaud on embryonic development: in vivo and in vitro studies. Journal of Ethnopharmacology 134 (2):393-8.

Wardihan, Rusdi M, Alam G, Lukman, Manggau M (2013) Selective Cytotoxicity Evaluation in Anticancer Drug Screening of Boehmeria virgata (Forst) Guill Leaves to Several Human Cell Lines: HeLa,WiDr, T47D and Vero. Dhaka University Journal of Pharmaceutical Sciences 12(2): 87-90. 